\title{
Determinants of Profitability of Broiler Production in the Out-growers Schemes in Southwest Nigeria
}

\author{
Submitted 14/03/21, $1^{\text {st }}$ revision 12/04/21, $2^{\text {nd }}$ revision 28/04/21, accepted 20/05/21
}

\author{
Sylvester Oluwadare Ojo ${ }^{1}$, Motunrayo Helen Falaye ${ }^{2}$, \\ Edward Temitope Ojaomo ${ }^{3}$
}

\begin{abstract}
:
Purpose: The study focused mainly on broiler production's determinants in the out-growers scheme in Southwest Nigeria. The objectives of this study were to examine the socio-economic characteristics of the participating farmers, examine the determinants of the costs and benefits analysis of broiler production in the out-grower scheme, examine the determinants of profitability, and determine the constraints inhibiting broiler production in the study areas.

Design/Methodology/Approach: A sample size of 90 broiler poultry farmers were randomly selected using a structured questionnaire, data were analyzed using descriptive statistics such as frequency distribution mean, and percentages were used to achieve some of the objectives, while production function analysis was used to analyze the determinants of profitability of broiler out-grower scheme in the study area.

Findings: The result reveals that majority 66.7 percent of the respondents in the study area, were male, and $33.3 \%$ of the respondents were female. The mean age was 43.3 years. Most of the respondents $(94.4 \%)$ were married, while few were single (5.6\%). The finding also revealed that the majority (80\%) of the respondents had tertiary education. The mean household size is 5 persons. Farmers with experience of 10-20 years were the majority with $77.5 \%$, while $13.7 \%$ of them had between 21-30 years of experience, while $7.7 \%$ had $>10$ years and $1.1 \%$ had $>30$ years broiler farming experience.

Practical Implications: This study also revealed that $63.0 \%$ of the respondents had access to one credit facility or the other, while the rest, $37.0 \%$, do not have access to any. Feed, drugs/ medication, and stock size significantly influenced broiler production in the out-growers scheme at $5 \%$ and $1 \%$ level of significance in the study area.

Originality/Value: It is therefore recommended that funds should be made available to the farmers by providing micro-credits to the farmers because inadequate funding was the highest constraint identified by the farmers.
\end{abstract}

Keywords: Broiler production, determinants, profitability, Southwest Nigeria.

JEL Codes: L6.

Research type: Research paper.

${ }^{1}$ Prof. Afe Babalola University, Ado-Ekiti, Nigeria. Department of Economics, soojo@abuad.edu.ng;

${ }^{2}$ Afe Babalola University, Ado-Ekiti, Nigeria, Department of Economics,

Falayemh@abuad.edu.ng;

${ }^{3}$ Afe Babalola University, Ado-Ekiti, Nigeria, Department of Agricultural Economics 


\section{Introduction}

The Agricultural sector in Nigeria has remained the most significant contributor to the Gross Domestic Product of the nation's economy. For the past two decades, it has contributed an average of 39\% of its GDP and employs nearly $60 \%$ of its workforce. Over $80 \%$ of the country's population living in rural areas is directly or indirectly dependent on agriculture for its livelihood (NBS, 2005).

The livestock sector plays a critical role in the rural economy and livelihood. In the Nigerian economy, the livestock sub-sector forms essential livelihood bedrock for the farmers, supporting agriculture in the form of critical inputs, contributing to the health and nutrition of the nation. Among livestock-based enterprises, poultry occupies an essential stand because of its potential to enormous ability to bring about rapid economic growth. The importance of the poultry sub-sector is chiefly in the provision of meat and egg as well as the provision of employment either directly or indirectly and the contribution to the revenue reserves (GDP) of the country.

Poultry production in Nigeria covers rural free-range systems, urban backyard systems, commercial production systems, and industrial integrated systems. The rural free-range and urban backyard systems comprise local birds of mixed breeds rose in a subsistence manner. The birds are allowed to move about in search of food. In the urban backyard system, provisions are usually made for supplementary feeding. The birds kept could be local breeds, exotic breeds, or a mixture of both. The commercial production system is highly specialized and industrialized, focusing on exotic breeds for meat and eggs. Unlike the rural and peri-urban systems with minimal input, commercial production requires enormous capital investment in production resources. The industrial and commercial systems invest in housing, feed mill, grandparent stock, parent stock, incubator, hatchery, slaughterhouse, and vehicles. The industrial/commercial operators are responsible for producing fertile eggs, dayold chicks, feeds, drugs, table eggs, and meat.

Broiler production is of considerable significance to the Nigerian economy. It is an essential source of animal protein. It also provides employment and regular income for the farmers. Broilers are birds that proliferate and reach marketable size after two to three months. They need enough feeds to maintain their body weight. Traditionally, broiler product has been a part-time or supplementary enterprise on many Nigeria farms (Uzegbu, 2007).

The efficiency of a farm/firm consists of three components: technical, allocative, and economic efficiencies. Technical efficiency is defined as producing a given level of output with a minimum level of inputs under specific technology. Allocative efficiency refers to the ability to choose the optimum combination of inputs at a given factor price. Economic efficiency or total efficiency is the product of both technical and allocative efficiencies. An economically efficient input-output combination will lie on both the frontier function and expansion path. Therefore, an economical, efficient farm/firm will produce a unit of output at the least possible cost. 
Out grower scheme is broadly defined as binding arrangements through which a firm ensures its supply of agricultural produce from an individual or groups of farmers. It facilitates a specially designed trade agreement between producers, processors, and traders, leading to vertical integration of the agricultural value chains (Katharina et al., 2010). Out grower scheme on many occasions has been referred to as contract farming with effective management, it can be a means to develop market and bring about the transfer of technical skills in a way that is profitable for both the contracting company and the farmers. This has been widely utilized to boost the production, marketability, and profitability of several crops and livestock.

\section{Methodology}

\subsection{Study Area}

The study area is South-Western Nigeria. This comprises six (6) states, namely: Lagos, Ogun, Oyo, Osun, Ondo, and Ekiti states. The region is located mainly in the tropical zone. It lies between latitudes $50 \mathrm{~N}$ and $90 \mathrm{~N}$ and longitudes $20 \mathrm{E}$ and $80 \mathrm{E}$. The Atlantic Ocean bounds it in the south, Kwara and Kogi state in the North, Edo state in the east, and Republic of Benin in the West. The people are mainly Christians and Muslims, while a lesser percentage of them are traditionalists. The residents are primarily farmers with other secondary livelihood activities in livestock production and trading. About 65percent of commercial poultry production in Nigeria is carried out in this area (PAN 2008; Okoruwa and Obayelu, 2004). Therefore, the SouthWestern zone is chosen for this study. Oyo and Osun States have a large population of farmers participating in broiler out-grower schemes in the southwest because of Tuns Farms and Amo farms' champions of out-grower schemes in the area.

\subsection{Methods of Data Collection}

Primary data was used in this study. Primary data were sourced from broiler farmers using a well-structured questionnaire obtained from all the farmers with the help of PAN and farm supervisors of Tuns and Amo Farms. Data on the socioeconomic characteristics of the respondents, cost of inputs, and value of outputs were collected.

\subsection{Sample Size and Sampling Technique}

A multistage sampling procedure was employed in the selection of the respondents. A multistage sample is often more precise than a simple random sample of the exact cost and usually more accurate than a cluster sample of the same total size. This sampling technique is much more flexible, economical, and efficient than one-stage sampling. It employs combinations of different sampling methods. A multistage sampling technique involving purposive, stratified, and simple random sampling will be used to select respondents. Oyo and Osun State will be selected from the southwest zone because of the large population of broiler farms participating in out-grower schemes. Secondly, two of the six senatorial zones in Oyo and Osun States with the highest number of poultry farms (broiler) will be chosen, followed by a random 
selection of three local governments from each chosen zone. The local government areas will be stratified based on the farm type (participants in Amo and Tuns outgrower schemes). Each stratum will be further stratified based on the scale of operation. Simple random sampling will finally be used to select respondents from each stratum. A total of 15 respondents will be selected from each stratum in the six local government areas chosen, making 90 respondents in all.

\subsection{Method of Data Analysis}

Descriptive statistics such as mean, standard deviation, frequency distribution and percentages will be used to analyse the socio-economic characteristics and constraints that are faced by the broiler farmers. The mean and the standard deviation will be derived using the following formula:

and

$$
\operatorname{Mean}(\overline{\mathrm{X}})=\sum \frac{X}{N}
$$

$$
\text { Standard deviation }=\sqrt{\frac{1}{\mathrm{~N}} \sum_{\mathrm{i}=1}^{\mathrm{N}}\left(\mathrm{x}_{1}-\mu\right)^{2}}
$$

where $X=$ the variable under consideration, e.g., age of farmers;

$\mathrm{N}=$ number of farmers;

$\mu=$ sample mean.

Gross margin analysis was used to determine the cost and returns from the broiler farmers, and the Net Farm Income was also estimated. According to Olukosi and Erhabor (1988), Net Farm Income (NFI) is the difference between the Gross Income (GI) and the total cost of production. It measures the strength and weakness of the farm. This was used to estimate the gross margin and the net income accruing to the broiler producers in the study area. The following equation represents the model for estimating the NFI:

$$
\begin{array}{lll}
\mathrm{NFI} & = & \mathrm{GI}-\mathrm{TVC}-\mathrm{TFC} \\
\mathrm{GM} & = & \mathrm{TVP}-\mathrm{TVC}
\end{array}
$$

$\begin{array}{rll}\text { where: NFI } & = & \text { Net Farm Income (Naira) } \\ \text { GI } & = & \text { Gross Income (Naira) } \\ \text { TVC } & = & \text { Total Variable Cost (Naira) } \\ \text { TFC } & = & \text { Total Fixed Cost (Naira) } \\ \text { TVP } & = & \text { Total Value of Production }\end{array}$

Total Variable Cost: These costs vary with output. They include feed, stock, labor, drug, vaccination, transportation, water, electricity, etc.

Total Fixed Cost: They are costs that do not vary with output levels in the short run (Olukosi and Erabor, 1988). This includes expenses on land, equipment, building, machinery. 


\subsection{The Production Function Model}

This research employed the production function analytical technique using the OLS estimation technique to estimate the parameters of the production function. The choice of the OLS technique is a result of its optimal properties of linearity, unbiasness, zero mean value of the random term, and minimum variance.

\subsection{Specification of the Production Function Model}

The production function was used to examine the resource-efficient input used by the respondents in the broiler production in the study area. Estimating the production function parameters was done using the ordinary least square method (OLS) of multiple regressions techniques. For this study, the functional forms were specified as:

$$
\mathrm{Y}_{\mathrm{i}}=\beta_{0}+\beta_{1} \mathrm{P}_{\mathrm{Li}}+\beta_{2} \mathrm{P}_{\mathrm{Dri}}+\beta_{3} \mathrm{P}_{\mathrm{Di}}+\beta_{4} \mathrm{P}_{\mathrm{Fi}}+\beta_{5} \mathrm{P}_{\mathrm{Kci}}+\beta_{6} \mathrm{P}_{\mathrm{Mi}}+\mathrm{u}_{\mathrm{i}}
$$

where:

$\mathrm{Y}_{\mathrm{i}}=$ Output level (kilograms of broiler produced)

$\mathrm{P}_{\mathrm{L}}=$ Labour cost ( $/$ per bird)

$\mathrm{P}_{\mathrm{Dr}}=$ Average cost of Medications ( $/$ per bird)

$\mathrm{P}_{\mathrm{D}}=$ Average cost of day-old chick ( / chick)

$P_{F}=$ Average feed cost $(\mathrm{Ng})$

$\mathrm{P}_{\mathrm{M}}=$ Average price of miscellaneous items (

$\mathrm{X}_{6}=$ Utilities and other expenses (

$\beta_{\mathrm{I}}-\beta_{6}=$ coefficients of parameters estimated

$\beta_{0}=$ Intercept.

\section{Results and Discussions}

\subsection{Socio -Economic Characteristics of the Respondents}

The socio-economic characteristics assessment for the farmers is shown in Table 1 below. The gender distribution of the broilers farmers reveals that majority 66.7 percent of the respondents in the study area were male, and $33.3 \%$ of the respondents were female. The result shows that broiler productions are practiced mainly by male farmers compared to female. This may be due to high energy involvement. The age distribution of the respondents shows that $29.9 \%$ of the respondents fall between ages $29-39$, and $51.2 \%$ of the respondents fall between ages $40-49$ and $16.7 \%$ and $2.2 \%$ fall between ages $50-59$ and $\geq 60$, respectively. This implies that most of the poultry broiler farmers were in their economically active and productive ages. It also means broiler production was embarked on by farmers who were physically and mentally fit to face challenges. The study agrees with Anwasia (2015), whose findings revealed that $69 \%$ of broiler farmers fell within the productive age range.

The marital status of the respondents reveals that $94.4 \%$ are married, $5.6 \%$ are single. This is following the findings of Ajala et al. (2007). This implies that most of the 
respondents are responsible, and the high number of married people in the business may lead to reduced labor cost as the children can substitute for labor in poultry production. The educational status of the respondents shows that $80.0 \%$ of the population attended tertiary institutions and $15.6 \%$ attended secondary institutions while $4.4 \%$ attended only primary institutions; therefore, it can be deduced that most of the farmers in the enterprise are educated at different levels. In the management of poultry enterprises, education is essential.

According to their household size, the distribution of respondents reveals that most of the respondents $(77.8 \%)$ fell within the household size of 5 to 10 persons. In comparison, the remaining $22.2 \%$ had below five persons, and the mean household size was five persons per household. The study agrees with Nwaru's (2004) findings, who reported that large household size enhances family labor availability since it reduces labor constraints in broiler production. The result of the access to credit of the respondents shows that $63.0 \%$ of the farmers have access to credit while the remaining $27.0 \%$ do not have access to credit. This indicates that quite many farmers have access to one type of credit or the other. Access to credit is believed to increase the productivity of the respondent, according to Ukoha et al. (2007).

The farming experience of the respondents shows that $7.7 \%$ has less than 10years of poultry farming experience, most of the farmers (77.5\%) has between 10 and 20 years of farming experience, $13.2 \%$ for at least five years in the study had between 21 and 30 years of experience, $1.1 \%$ had more than 30 years of experience area. This suggests that most of the farmers are not new entrants in the industry. It is expected that productivity increases with years of experience, and it increases the knowledge of adequate input combinations.

Table 1. Socio-Economic Characteristics of the Respondents.

\begin{tabular}{|l|l|l|}
\hline Variables & Frequencies & Percentages \\
\hline Gender & & \\
\hline Male & 60 & 66.7 \\
\hline Female & 30 & 33.3 \\
\hline Age Group (years) & & \\
\hline $29-39$ & 27 & 29.9 \\
\hline $40-49$ & 46 & 51.2 \\
\hline $50-59$ & 15 & 16.7 \\
\hline$\geq 60$ & 2 & 2.2 \\
\hline Mean Age=43.3years & & \\
\hline Marital Status & & \\
\hline Married & 85 & 94.4 \\
\hline Single & & 5.6 \\
\hline Level of Education & 5 & \\
\hline BSC/ HND & & 44.4 \\
\hline OND/NCE & 40 & 35.6 \\
\hline Secondary & 32 & 15.6 \\
\hline & 14 &
\end{tabular}




\begin{tabular}{|l|l|l|}
\hline Primary & 4 & 4.4 \\
\hline Household Size & & \\
\hline$<5$ & 44 & 38.3 \\
\hline $5-1$ & 71 & 61.7 \\
\hline Mean size = 5 Persons & & \\
\hline Access to Credit & & \\
\hline Yes & 70 & 63.0 \\
\hline No & 20 & 27.0 \\
\hline Farming Experience & & \\
\hline$<10$ & 7 & 7.7 \\
\hline $10-20$ & 70 & 77.5 \\
\hline $21-30$ & 12 & 13.2 \\
\hline$>30$ & 1 & 1.1 \\
\hline Mean Experience $=\mathbf{1 5 . 3 5 y e a r s}$ & & \\
\hline TOTAL & $\mathbf{9 0}$ & $\mathbf{1 0 0}$ \\
\hline
\end{tabular}

Source: Field survey, 2019.

\subsection{Cost and Return Schedule of Broiler Enterprise in the study area}

The result of the profitability of the broiler enterprise is presented in Table 2. It was found that over $94 \%$ of the cost of production was on account of variable inputs. It was revealed that the cost of feed accounted for the bulk of the variable cost and, as a matter of fact, the cost of production in general. This goes in line with Sekoni's (2000) and Umar's (2012) study that indicated that feed cost is the highest single variable cost in animal production. The depreciation was calculated for each fixed cost, and the result revealed that the highest cost was incurred on buildings and pens. Sales of broilers are the significant source of revenue in the enterprise. The extremely high percentage of the cost of feed-in broiler production is in line with the cost structure for the poultry industry in general (Umar, 2012). The net farm income of the broiler production in the study area is N202672.8.

Table 2. Cost and Returns of Broiler Production in the study area

\begin{tabular}{|l|l|l|}
\hline Items & Average value(m) & percentage \\
\hline Revenue & & \\
\hline Sales of Birds & 3262500 & 97.5 \\
\hline Sales of Dung & 83620 & 2.5 \\
\hline Total revenue & $\mathbf{3 3 4 6 1 2 0}$ & $\mathbf{1 0 0}$ \\
\hline Variable costs & & \\
\hline Costs of Birds & 37381 & 2.0 \\
\hline Costs of Feed & 1184100 & 92.2 \\
\hline Costs of Medication & 48955.6 & 3.8 \\
\hline Costs of Transportation & 6042.2 & 0.5 \\
\hline Costs of Labour & 7243.3 & 0.6 \\
\hline Other Costs & 800 & 0.06 \\
\hline Total Variable Costs & $\mathbf{1 2 8 4 5 2 2 . 1}$ & $\mathbf{1 0 0}$ \\
\hline & & \\
\hline
\end{tabular}




\begin{tabular}{|l|l|l|}
\hline Fixed costs & & \\
\hline Buildings and Pens & 22071.429 & 63.3 \\
\hline Cages & 5192.8 & 14.9 \\
\hline Wheelbarrow & 1472.500 & 4.2 \\
\hline Generator & 4305.796 & 12.4 \\
\hline Other items & 1828.57 & 5.2 \\
\hline Total fixed costs & $\mathbf{3 4 8 7 1 . 0 9 5}$ & $\mathbf{1 0 0}$ \\
\hline Total costs (tfc+tvc) & $\mathbf{1 3 1 9 3 9 3 . 1 9 5}$ & \\
\hline Net farm income & $\mathbf{2 0 2 6 7 2 6 . 8}$ & \\
\hline
\end{tabular}

Source: Own creation.

\subsection{Determinants of Profitability of Broiler Production in the study area}

The result of the determinants of profitability of broiler production in the study area is presented in Table 3. From the results, feed consumed, cost of medication, and cost of Day-Old Chicks (DOC) were the inputs that had a significant influence on broiler production in the study area. Both feed and DOC costs were high at $1 \%$, while drugs administered were significant at 5\%, and transport and labor costs were not high.

The cost of feed and drugs were high and negatively influenced broiler production in the study area; this implies that a unit increase in the extra cost inquired on Feed and drugs will lead to a -0.236 and -4.911 percent decrease in the revenue of the broiler farmers, which will, in turn, makes the farmer resource inefficient. While the cost of the day-old chicks positively influenced broiler production in the out-growers scheme, the higher the stock size, the more broilers produced and the higher the return to scale.

The use of labor by the farmers was statistically insignificant and negatively related to broiler production in the study area. Thus, the more labor used in the production process, the lower the productivity. This may be a result of the scale of production in the study area. Thus, increasing labor in the production process that is mainly tiny scale will increase the cost of production without a substantial increase in broiler output.

Concerning the signs of the coefficient of the variables, they are essential in explaining the level of observed profitability among broiler producers. A negative sign implies that the variable has the effect of reducing the profitability, while a positive sign increases it. From the result, Feed consumed, drug/ medication, and size of stock are the inputs that significantly influence broiler production in the study area.

However, one of the identified socioeconomic variables (Gender) had a significant influence on broiler production. This means the null hypothesis that Socioeconomic characteristics of broiler farmers do not significantly determine their profitability cannot be accepted. However not included, the level of technology not included may be an essential determinant of the farmer's profitability. 
Table 3. Determinants of Profitability of Broiler Farmers in the study area

\begin{tabular}{|c|c|c|c|c|}
\hline Variables & Coefficient & $\begin{array}{l}\text { Standard } \\
\text { Error }\end{array}$ & $\mathrm{T}$ - value & Sig. \\
\hline (Constant) & -478992.913 & 210413.375 & $-2.276 * * *$ & .026 \\
\hline Gender & 110922.888 & 28917.034 & $3.836 * * *$ & .000 \\
\hline Age & 1190.782 & 2728.092 & .436 & .664 \\
\hline Marital status & -44511.562 & 71613.777 & -.622 & .536 \\
\hline Educational status & -2837.135 & 5726.101 & -.495 & .622 \\
\hline Household size & -3955.503 & 14380.900 & -.275 & .784 \\
\hline $\begin{array}{l}\text { Farming } \\
\text { Experience }\end{array}$ & -2642.127 & 3428.481 & -.771 & .443 \\
\hline Creditacces & 64600.818 & 33847.621 & 1.909 & .060 \\
\hline Labour cost & -0.062 & 0.036 & -1.714 & .083 \\
\hline Feed cost & -.306 & .063 & $-4.830 * * *$ & .000 \\
\hline $\begin{array}{l}\text { Drug/medication } \\
\text { cost }\end{array}$ & -4.911 & 2.329 & $-2.109 * * *$ & .038 \\
\hline Doc/ stock cost & 8.810 & .592 & $14.891 *$ & .000 \\
\hline Transportation cost & 0.982 & 1.505 & .653 & .516 \\
\hline $\begin{array}{l}\text { R-Square } \\
\text { Adjusted R- Square } \\
\text { F-STAT }\end{array}$ & $\begin{array}{l}0.876 \\
0.858 \\
49.999 \\
\end{array}$ & & & \\
\hline
\end{tabular}

Note: ***, ***, * Represents significance level at 5\%, 10\%, and 1\% respectively.

Source: Own creation.

\subsection{Constraints of Broiler Production in the study area}

Table 4 below shows the distribution of respondents according to the constraints they faced in broiler production. Respondents rated the high cost of input as the major constraint. Anwasia (2015) also reported that the high cost of input such as feed is the major constraint in the industry. The high cost of inputs makes it difficult for an existing enterprise to expand the scale of their production, thereby causing stagnation and or low returns. About $8.13 \%$ of the respondents stated an inadequate market for the outputs or market glut. Glut thereby will cause a fall in price which will reduce the returns. Availability of funds is another constraint being faced by the respondents.

About $14.63 \%$ of the respondents stated that lack of funds is a problem in their various enterprises. This can be due to the high-interest rates or collateral requested by the financial institution. This could be why farmers could not afford to get credits to acquire necessary inputs or expand their enterprises at will. Pests and diseases are also a constraint facing the enterprise, and this could be the cause of inefficiency in the enterprise because the mortality rate will be high, and productivity will be reduced. $16.26 \%$ of the respondents stated that transportation is a problem in their enterprises.

This is because of the poor road network causing some birds to die on the way to the market. The respondents pointed to storage facilities as the least important problem to their business. 
Table 4. Distribution of Respondents According to Constraints they faced

\begin{tabular}{lll}
\hline Constraints & Frequency & Percentage \\
\hline Pest and diseases outbreak & 20 & 16.26 \\
High cost of inputs & 30 & 24.39 \\
Inadequate storage facilities & 33 & 26.83 \\
Transportation & 12 & 9.76 \\
Lack of funds & 18 & 14.63 \\
Lack of market & 10 & 8.13
\end{tabular}

Note: *Multiple Responses.

Source: Own creation.

\section{Conclusion}

Feed was the highest variable cost item in the broiler enterprise in the study area. The determinants of profitability were also analysed, and the result showed that the socioeconomic characteristics influenced the farmers' profitability level; only gender out of the socio-economic characteristics identified significantly influenced farmers' profitability level.

Therefore, it can be concluded that most of the broiler farmers in the study area were operating on a small scale. The level of profitability of the broiler enterprise can be increased through better use of resources available, given technology, and addressing the constraints to the enterprise. The high cost of inputs was the highest constraint in the study area, followed by the inadequate market and inadequate funds. Based on the conclusion, it can therefore be recommended that:

- Funds should be made available to the farmer by providing micro-credits to the farmers because inadequate funding was the highest constraint identified by the farmers.

- Policies and programmes that will make micro-credits from appropriate agencies accessible should be made by the regulatory bodies. Programmes that will encourage and facilitate economic production of poultry feed ingredients like maize, wheat, soya-beans should be instituted for least cost production of the feed.

\section{References:}

Anwasia, A.I. 2015. Production Efficiency of Small-Scale Broiler Farmers in Delta State. Nigeria, A.

Food and Agriculture Organisation. 2013. Poultry Sector Nigeria. FAO Animal Production and Health Livestock Country Reviews. Paper 50, Rome.

Food and Agriculture Organisation of the United Nations (FAOSTAT). 2008. FAOSTAT dat. Rome. Retrieved from: http://www.faostat.fao.org/.

Kumbhakar, S.C., Lovell, C.A. 2000. Stochastic Frontier Analysis. Cambridge University Press, Cambridge.

Nwaru, J.C. 2003. Gender and Relative Production Efficiency in Food Crop Farming. 
Owusu-Afari, E. 2010. Ghana - Problems in poultry industry. Meat Trade News Daily. Retrieved from: www. meattradenewsdaily.co.uk/ Ghana - Problems in poultry industry.

Seidu, A. 2008. Farm Level Efficiency of Broiler Farms in Brong Ahafo Region of Ghana. Unpublished Dissertation, University of Cape Coast, Ghana.

Ukoha, O.O., Agustine, A.C. 2007. Technical Efficiency of Small-Scale Poultry Egg.

Umar, M. 2012. Economic Analysis of Poultry Egg Production in Bauchi State. Nigeria, A.

Uzegbu, H.O., Ndelekwute, E.K., Abdu, L.S. 2007. Effective of inclusion of Bambara groundnut (Voanzea subterenea) waste meal on metabolizable -energy and protein of broiler chickens. Proceedings of 41st Annual Conference of Agricultural Society of Nigeria, 348-352. 